\title{
Kinerja Pegawai Kecamatan Jombang Kota Cilegon Serta Faktor yang Mempengaruhinya
}

\author{
Nafiudin ${ }^{1}$ \\ Suhartini $^{2}$ \\ Fakultas Ekonomi dan Bisnis, Universitas Serang Raya \\ nafiuddin08@gmail.com \\ suhartini@unpas.ac.id
}

\begin{abstract}
Abstrak
Kepemimpinan dan komunikasi merupakan faktor yang dapat menentukan tingkat kinerja pegawai suatu instansi. Semakin tinggi tingkat kepemimpinan dan komunikasi di Kecamatan Jombang maka semakin bagus kinerja pegawai di suatu instansi tersebut. Oleh karena itu, penelitian ini bertujuan untuk mengetahui pengaruh kepemimpinan dan komunikasi terhadap kinerja pegawai di Kecamatan Jombang. Populasi dalam penelitian ini adalah pegawai Kecamatan Jombang. Jumlah sampel sebanyak 45 pegawai dengan menggunakan teknik sampling jenuh. Data dalam penelitian ini diperoleh dari data kepegawaian Kecamatan Jombang Kota Cilegon dan diolah dengan menggunakan program SPSS versi 16. Berdasarkan hasil penelitian dapat disimpulkan bahwa: 1) terdapat pengaruh yang signifikan antara kepemimpinan terhadap kinerja, 2) terdapat pengaruh yang signifikan antara komunikasi terhadap kinerja, dan 3) terdapat pengaruh secara simultan antara kepemimpinan dan komunikasi terhadap kinerja.
\end{abstract}

Kata Kunci: Kepemimpinan, Komunikasi, Kinerja

\section{Pendahuluan}

Setiap organisasi atau perusahaan memerlukan sumber daya untuk mencapai tujuannya. Sumber daya yang dimiliki dapat dikategorikan atas enam tipe yaitu manusia, finansial, fisik, teknologi, metode, dan pasar. Aset paling penting yang harus dimiliki manajemen dalam organisasi atau perusahaan adalah tenaga kerja manusia. Sumber daya manusia adalah orang-orang yang merancang, menghasilkan barang atau jasa, mengawasi mutu, memasarkan produk, mengalokasikan sumber daya finansial, serta merumuskan seluruh strategi dan tujuan organisasi.

SDM digunakan untuk menggerakkan dan mengyinergikan sumber daya lainnya untuk mencapai tujuan organisasi. Sumber daya manusia menjadi salah satu penentu organisasi dapat berjalan dengan baik atau tidak. Banyaknya keunggulan yang dimiliki, belum tentu dapat memaksimalkan produktivitas dan laba tanpa adanya komunitas karyawan yang berkompeten di dalam organisasi atau perusahaan. Untuk mencapai hal tersebut perusahaan harus mampu menciptakan situasi yang dapat meningkatkan kemampuan dan ketrampilan karyawan secara optimal.

Kinerja merupakan suatu yang lazim digunakan untuk memantau produktivitas kerja sumber daya manusia, baik yang berorientasi pada produksi barang, jasa maupun pelayanan. Salah satu di antara beberapa faktor kinerja karyawan, yang paling berpengaruh adalah lingkungan kerja.

${ }^{1}$ Korespondensi: Nafiudin. Universitas Serang Raya. Jl. KH. Amin Jasuta No 15C Kaloran Brimob, Serang. nafiuddin08@gmail.com

${ }^{2}$ Korespondensi: Suhartini. Universitas Serang Raya. J1. KH. Amin Jasuta No 15C Kaloran Brimob, Serang. suhartini@unpas.ac.id 
Lingkungan kerja ada dua macam, yakni lingkungan kerja fisik dan non fisik. Lingkungan fisik antara lain berupa fasilitas kerja seperti peralatan kerja, ruangan, kursi, dan lain-lain. Sementara lingkungan non fisik antara lain gaya kepemimpinan pengelola yang partisipatif, mutu hubungan vertikal horizontal, serta lingkungan sosial.

Berdasarkan wawancara dengan pegawai di Kecamatan Jombang Kota Cilegon, bahwa kinerja pegawai yang kurang maksimal dapat mengakibatkan penurunan terhadap kualitas dan kuantitas pelayanan, seperti kurangnya inisiatif, ketidakmampuan dalam memecahkan masalah, tidak tercapainya target kerja, tidak tepat waktu dan tidak mampu bekerjasama dengan baik antar sesama pegawai.

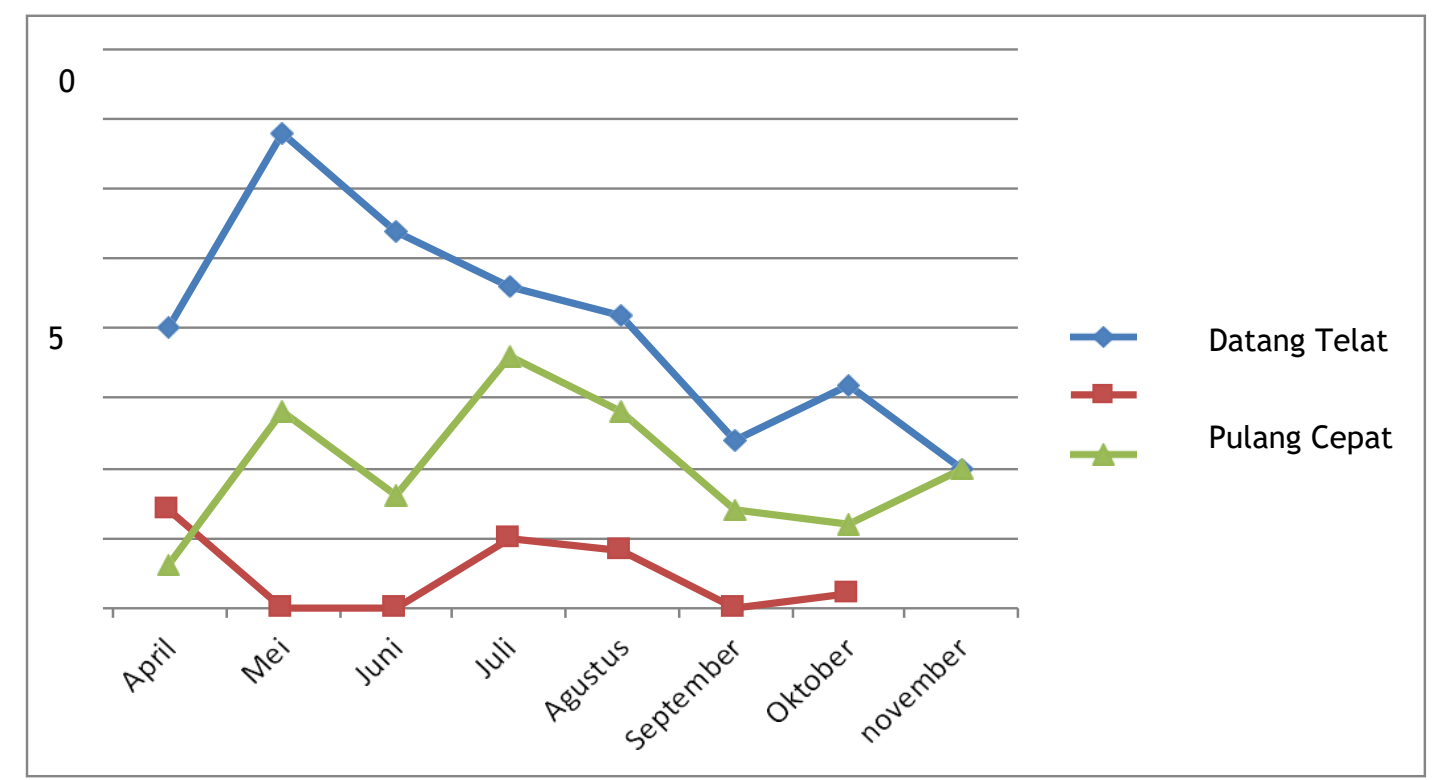

Grafik 1. Grafik Kehadiran Pegawai Kecamatan Jombang

Sumber: Data Kepegawaian Kecamatan Jombang tahun 2017

Berdasarkan kesimpulan observasi awal bahwa kinerja pegawai Kecamatan Jombang Kota Cilegon, mengalami penurunan seperti yang sudah dijelaskan sebelumnya berdasarkan grafik kehadiran pegawai Kecamatan Jombang pada bulan Mei mengalami peningkatan pegawai yang datang terlambat/tidak apel pagi. Setelah itu pada bulan Juni mengalami peningkatan pegawai yang tidak hadir atau tanpa keterangan, dan terlihat pegawai yang pulang cepat pada bulan Juli.

Menurut pengamatan awal penulis berdasarkan wawancara dengan pegawai Kecamatan Jombang Kota Cilegon, menemukan bahwa Kepemimpinan yang dilakukan oleh Camat masih kurang dalam hal pemberian reward pada pegawai. Hal tersebut berdasarkan hasil wawancara dengan Ibu "TK" pegawai Kecamatan beliau mengatakan: "pernah kejadian pemberian hadiah kepada pegawai kecamtan yang berprestasi, tapi itu sudah lama tiga tahun lalu lebih tepatnya tahun 2015". Pada observasi yang dilaksanakan oleh peneliti, menemukan bahwa komunikasi pegawai di Kecamatan Jombang Kota Cilegon, masih kurang terjalinnya hubungan yang harmonis antara pegawai dengan pegawai sejawat lainnya.

Penelitian ini dilakukan untuk mengembangkan hasil dari penelitian-penelitian terdahulu yang memiliki variable yang sama dengan menggunakan obyek serta lokasi penelitian yang berbeda. Misalnya perbedaan penelitian dari (Ningsih, 2014) yaitu Pengaruh Kepemimpinan, Motivasi, Lingkungan Kerja dan komunikasi terhadap Kinerja Karyawan PT. Pinnacle Apparels Semarang yaitu perbedaan yang terletak pada penambahan variable bebas, selain itu juga perbedaan pada penambahan metode uji asumsi klasik yaitu terdiri dari uji normalitas, uji multikolonieritas, uji heteroskedestisitas, uji autokorelasi pada penelitian ini. Hasil Penelitian dari Dian Venti 
Riandaningsih tersebut yaitu berpengaruh signifikan terhadap kinerja karyawan. Berdasarkan latar belakang di atas maka peneliti mengangkat judul: Kinerja Pegawai di Kecamatan Jombang Kota Cilegon serta faktor yang mempengaruhinya.

\section{Metode Penelitian}

Metode yang digunakan dalam penelitian ini adalah desain penelitian Deskriptif dan Assosiatif. Metode deskriptif merupakan penelitian yang dilakukan untuk mengetahui nilai variabel mandiri, baik satu variable atau lebih (independen) tanpa membuat perbandingan, atau menghubungkan dengan variable yang lain (Sugiyono, 2005). Metode assosiatif merupakan penelitian yang bertujuan untuk mengetahui pengaruh ataupun juga hubungan antara dua variabel atau lebih. Penelitian ini mempunyai tingkatan tertinggi dibandingkan dengan diskriptif dan komparatif karena dengan penelitian ini dapat dibangun suatu teori yang dapat berfungsi unguk menjelaskan, meramalkan dan mengontrol suatu gejala (Sugiyono, Pendekatan Kuantitatif, Kualitatif, dan R\&B, 2010). Menurut (Hasan, 2002) populasi (universe) adalah totalitas dari semua objek atau individu memiliki karakteristik tertentu, jelas dan lengkap yang akan diteliti (bahan penelitian). Untuk itu populasi dalam penelitian ini adalah 45 pegawai di Kecamatan Jombang. Sebagaimana yang dikemukakan oleh (Sugiyono, Statistika untuk Penelitian, 2014)menyatakan bahwa: "Sampel adalah bagian dari jumlah dan karakteristik yang dimiliki oleh populasi." Agar sampel yang diambil representatif, maka diperlukan teknik pengambilan sampel. Penentuan sampel perlu dilakukan dengan cara yang dapat dipertanggungjawabkan untuk mendapatkan data yang benar, sehingga kesimpulan yang diambil dapat dipercaya. Teknik pengambilan sampel yang digunakan adalah sampling jenuh. Menurut (Sugiyono, Statistika untuk Penelitian, 2014), bahwa: "teknik sampling jenuh merupakan teknik penentuan sampel bila semua anggota populasi digunakan sebagai sampel." Hal ini dikarenakan populasi yang digunakan pada penelitian ini relatif kecil. Maka sampel yang diteliti sebanyak 45 pegawai di Kecamatan Jombang Kota Cilegon.

\section{Teknik Pengumpulan Data}

1. Penelitian Pustaka (Library Research)

Yaitu pengumpulan data yang dilakukan dengan jalan membaca dan mempelajari literatur, laporan atau tulisan ilmiah, catatan kuliah dan agenda atau file perpustakaan yang semuanya memiliki kaitan langsung dengan masalah yang diteliti.

2. Penelitian Lapangan (Field Research)

a. Pengamatan (Observasi), yaitu teknik pengumpulan data dengan cara penelitian dan pengamatan langsung pada objek yang diteliti.

b. Angket (Questioner), yaitu teknik pengumpulan data yang dilakukan dengan cara memberi seperangkat pernyataan terulis kepada responden untuk dijawab.

3. Pengukuran Variabel

Dalam pengukuran ini, menggunakan skala pengukuran yang dinamakan skala pengukuran skala Likert. Yang dimana menurut Sugiono menjelaskan, skala Likert digunakan untuk mengukur sikap, pendapat, dan presepsi seseorang atau sekelompok orang tentang kejadian atau gejala sosial. Dalam penelitian gejala sosial ini telah ditetapkan secara spesifik oleh peneliti, yang selanjutnya disebut sebagai variable penelitian.

\section{Teknik Analisis Data}

1. Uji Validitas

Uji validitas digunakan untuk mengukur sah atau tidaknya suatu kuesioner. Suatu kuesioner dikatakan valid jika pertanyaan pada kuesioner mampu mengungkapkan sesuatu yang akan diukur oleh kuesioner tersebut. Untuk mengukur validitas dapat dilakukan dengan melakukan 
korelasi antar skor butir pertanyaan dengan total skor konstruk atau variable. Hasil penelitian yang valid bila terdapat kesamaan antara data yang terkumpul dengan data yang sesungguhnya terjadi pada objek yang diteliti.

2. Uji Reliabilitas

Uji reliabilitas adalah serangkaian pengukuran atau serangkaian alat ukur yang memiliki konstitensi bila pengukuran yang dilakukan dengan alat ukur itu dilakukan secara berulang. Suatu kuesioner dikatkan reliabel atau handal jika jawaban seseorang terhadap pernyataan adalah konsisten atau stabil dari waktu ke waktu.

3. Uji Normalitas Data

Uji normalitas bertujuan untuk menguji apakah dalam model regresi, variable penganggu atau residual memiliki distribusi normal. Seperti diketahui bahwa uji t dan uji f mengasumsikan bahwa nilai residual mengikuti distribusi normal.

4. Analisis Regresi Berganda

Untuk mengukur pengaruh antara analisis jabatan dan penempatan pegawai dengan kinerja pegawai dengan mengunakan metode analisis regresi berganda. Rumus yang dipergunakan adalah:

$\mathrm{Y}=\mathrm{a}+\mathrm{b} 1 \mathrm{x} 1+\mathrm{b} 2 \mathrm{x} 2$

Keterangan:

$\mathrm{Y}=$ Variabel dependent (Kinerja Pegawai)

$\mathrm{A}=$ Konstanta

$\mathrm{X} 1=$ Variabel Indepnden 1 (Analisis Jabatan)

$\mathrm{X} 2$ = Variabel Indepnden 2 (Penempatan Pegawai)

b1 $=$ Koefesien Regresi 1 Analisis Jabatan

b2 = Koefesien Regresi 2 Penempatan Pegawai

5. Analisis Koefesien Determinasi

Koefesien determinasi menunjukan suaru proposi dari varian yang dapat diterangi oleh persamaan regresi terhadap variable total. Nilai koefesien korelasi lebih besar dari 0,5 menunjukan variable bebas dapat menjelaskan variable terikat dengan baik atau kuat (signifikan), sama dengan 0,5 atau kurang dari 0,5 relatif kurang baik.

Rumus yang digunakan sebagai berikut

$\mathrm{Kd}=\mathrm{R} 2 \mathrm{X} 100 \%$

Keterangan:

$\mathrm{Kd}=$ Koefesien Determinasi

$\mathrm{R}=$ Koefesien Korelasi

6. Pengujian Hipotesis

Untuk memastikan hasil yang diperoleh melalui pertimbangan korelasi, maka harus dilakukan pengujian hipotesis untuk membuktikan hasil yang telah diperoleh tersebut.

a. Pengujian Hipotesis Secara Parsial (Uji T)

Kriteria pengambilan keputusan digunakan pengujian dengan menggunakan statistik uji $\mathrm{t}$ yaitu: 
Dimana:

$\mathrm{b}=$ Koefesien regresi sample

$\beta=$ Koefesien regresi populasi

$\mathrm{S}_{\mathrm{b}}=$ Galat baku koefesien regresi

Berikut formulasi $\mathrm{H} 0$ dan $\mathrm{H} 1: \mathrm{X} 1$

$\mathrm{H} 0:=0$, artinya tidak ada pengaruh yang signifikan dari Kepemimpinan terhadap kinerja pegawai Lecamatan Jombang Kota Cilegon

$\mathrm{H} 1: \neq 0$, artinya terdapat pengaruh yang signifikan dari Kepemimpinan terhadap kinerja pegawai Keacamatan Jombang Kota Cilegon

$\mathrm{H} 2: \mathrm{X} 2$

$\mathrm{H} 0:=0$, artinya tidak ada pengaruh yang signifikan dari komunikasi pegawai terhadap kinerja pegawai Kecamatan Jombang Kota Cilegon

$\mathrm{H} 1: \neq 0$, artinya terdapat pengaruh yang signifikan dari penempatan pegawai terhadap kinerja pegawai Kecamatan Jombang Kota Cilegon

Setelah memperoleh nilai dari hasil perhitungan uji t diatas, maka langkah selanjutnya yang akan dilakukan adlah menguji nilai tersebut dengan menggunakan uji hipotesis pada t. adapun kriteria penerimaan hipotesis adalah sebagai berikut:

1) Jika t hitung $<\mathrm{t}$ table $\mathrm{df}=\mathrm{n}-2$ maka $\mathrm{H} 0$ diterima dan $\mathrm{H} 1$ ditolak.

2) Jika thitung $>\mathrm{t}$ table $\mathrm{df}=\mathrm{n}-2$ maka $\mathrm{H} 0$ ditolak a dan $\mathrm{H} 1$ diterima.

b. Pengujian Hipotesis Secara Simultan (Uji F)

$t=\frac{(b-\beta)}{s b}$ Menentukan Nilai F $F_{\text {hitung }}$ dengan rumus, dimana:

$\mathrm{R}^{2}=$ Koefesien regresi berganda

$\mathrm{k}=$ Jumlah variable independent

$\mathrm{n}=$ Junlah anggota sampel

$\mathrm{F}=$ Nilai $\mathrm{F}$ yang dihitung

Menentukan nilai taraf signifikan untuk penelitian ini penulis mengambil tingkat keyakinan sebesar 95\% sehingga tingkat kesalahan $(\alpha)$ sebesar 5\% atau $\alpha=0,05$. Untuk uji ini diperlukan mengetahui derajat kebebasan (dk), dan untuk mencari dk pembilang digunakan nilai ke-1, yaitu variable dikurangi 1 Untuk dk penyebut digunakan nilai n-k, yaitu jumlah sampel dikurangi jumlah variable. Adapun kriteria penerimaan hipotesis adalah sebagai berikut:

1) Jika $F_{\text {hitung }}>F_{\text {table }} \mathrm{df}=\mathrm{n}-3$ maka $\mathrm{H}_{0}$ ditolak dan $\mathrm{H}_{1}$ diterima. Artinya terdapat pengaruh yang signifikan dari variabel $\mathrm{X}_{1}$ dan variabel $\mathrm{X}_{2}$ terhadap variabel $\mathrm{Y}$.

2) Jika $F_{\text {hitung }}<F_{\text {tabledf }}=n-3$ maka $H_{1}$ ditolak dan $\mathrm{H}_{1}$ diterima. Artinya tidak terdapat pengaruh yang signifikan dari variabel $\mathrm{X}_{1}$ dan variabel $\mathrm{X}_{1}$ terhadap variabel $\mathrm{Y}$.

Fhitung $=\frac{R^{2} / k}{\left(1-R^{2}\right) /(n-k-1)} \mathrm{R} 2=$ Koefesien regresi berganda

$\mathrm{k}=$ Jumlah variable independent

$\mathrm{n}=$ Junlah anggota sampel 
$\mathrm{F}=$ Nilai $\mathrm{F}$ yang dihitung

Menentukan nilai taraf signifikan untuk penelitian ini penulis mengambil tingkat keyakinan sebesar 95\% sehingga tingkat kesalahan $(\alpha)$ sebesar 5\% atau $\alpha=0,05$. Untuk uji ini diperlukan mengetahui derajat kebebasan (dk), dan untuk mencari dk pembilang digunakan nilai ke-1, yaitu variable dikurangi 1 Untuk dk penyebut digunakan nilai n-k, yaitu jumlah sampel dikurangi jumlah variable. Adapun kriteria penerimaan hipotesis adalah sebagai berikut:

1) Jika $F_{\text {hitung }}>F_{\text {table }} \mathrm{df}=\mathrm{n}-3$ maka $\mathrm{H}_{0}$ ditolak dan $\mathrm{H}_{1}$ diterima. Artinya terdapat pengaruh yang signifikan dari variabel $\mathrm{X}_{1}$ dan variabel $\mathrm{X}_{2}$ terhadap variabel $\mathrm{Y}$.

2) Jika $F_{\text {hitung }}<F_{\text {tabledf }}=n-3$ maka $H_{1}$ ditolak dan $\mathrm{H}_{0}$ diterima. Artinya tidak terdapat pengaruh yang signifikan dari variabel $\mathrm{X}_{1}$ dan variabel $\mathrm{X}_{2}$ terhadap variabel $\mathrm{Y}$.

\section{Hasil}

\section{Uji Normalitas}

Berdasarka tabel one-sample Kolmogrof-Smirnov Test di atas dapat diketahui bahwa data terdistribusi normal jika nilai signifikasi $>$ dari nilai $(\alpha) 0,05$ dan sebaliknya data dikatakan tidak terdistribusi normal jika nilai signifikansi $<$ dari nilai $(\alpha) 0,05$. Hasil yang diperoleh dari data di atas menunjukan nilai statistic Asymp. Sig. (2-tailed) sebesar 0,498. Sehingga dapat disimpulkan bahwa data tersebut terdistribusi normal karena lebih dari nilai $(\alpha) 0,05$.

\section{Uji Multikolonearitas}

Berdasarkan hasil uji Multikolonearitas dapat dilihat bahwa nilai tolerance 0,587 > 0,10 dan untuk nilai variabel Variance Inflation Factor (VIF) 1,704 < 10 yang berarti pada variabel ini tidak terjadi multikolonearitas antar variabel independent dalam model regresi, variabel independent menunjukan adanya multikolonearitas jika nilai tolerance $\leq 0,10$ atau sama dengan nilai Variance Inflation Factor (VIF) $\geq 0,10$.

Setelah melihat uji asumsi klasik di atas, maka dapat disimpulkan bahwa regresi ini layak dilanjutkan ke pengujian tahap berikutnya, karena bebas dari uji normalitas, multikolonearitas.

\section{Analisis Regresi Linear Berganda}

Berdasarkan hasil uji hipotesis, maka dapat dibentuk persamaan sebagai berikut:

$$
\begin{aligned}
& Y=a+b_{1} X_{1}+b_{2} X_{2}+e \\
& Y=4,992+0,382 X_{1}+0,609 X_{2}+e
\end{aligned}
$$

Dari persamaan tersebut dapat diinterpretasikan sebagai berikut:

a. Konstanta $b_{0}=4,992$ meyatakan bahwa jika kepemimpinan dan komunikasi sama dengan nol dan tidak ada perubahan, maka kinerja sebesar 4,992.

b. Nilai koefisien regresi dari kepemimpinan sebesar 0,382 yang artinya bahwa setiap pemimpin akan meningkatkan kinerja sebesar 0,382 .

c. Koefisien regresi $b_{2}=0,609$ meyatakan bahwa jika kepemimpinan dan komunikasi sama dengan nol, maka meningkatkan kinerja sebesar 0,609.

d. Variabel baru yang tidak diteliti dilambangkan dengan e yang berarti error atau residual. 


\section{Uji Hipotesis Secara Parsial (Uji t)}

Hasil pengujian dengan SPSS untuk variabel $\mathrm{X}_{1}$ (Kepemimpinan) diperoleh nilai signifikansi 0,012 $<0,05$ dan nilai $t_{\text {hitung }} 2,636>t_{\text {tabel }} 1,679$. Sehingga $\mathrm{H}_{0}$ ditolak dan $\mathrm{H}_{\mathrm{a}}$ diterima yang berarti terdapat pengaruh $\mathrm{X}_{1}$ (kepemimpinan) terhadap $\mathrm{Y}$ (kinerja). Sedangkan untuk $\mathrm{X}_{2}$ (Komunikasi) diperoleh nilai signifikansi $0,010<0,05$ dan nilai thitung 2,690 $>t_{\text {tabel }} 1,679$. Sehingga $\mathrm{H}_{0}$ ditolak dan $\mathrm{H}_{\mathrm{a}}$ diterima yang berarti terdapat pengaruh $\mathrm{X}_{2}$ (Komunikasi) terhadap $\mathrm{Y}$ (Kinerja).

\section{Uji Hipotesis Secara Simultan (Uji F)}

Hasil pengujian dengan SPSS untuk variabel $\mathrm{X}_{1}$ (Kepemimpinan) dan $\mathrm{X}_{2}$ (Komunikasi) diperoleh nilai signifikansi $0,000<0,05$ dan nilai $F_{\text {hitung }} 19,859>\mathrm{F}_{\text {tabel }} 3,20$, sehingga $\mathrm{H}_{0}$ ditolak dan $\mathrm{H}_{\mathrm{a}}$ diterima yang berarti terdapat pengaruh $\mathrm{X}_{1}$ (Kepemimpinan) dan $\mathrm{X}_{2}$ (Komunikasi) secara simultan terhadap Y (Kinerja).

Tabel 1. Koefisien Determinasi $\left(\mathrm{R}^{2}\right)$ Model Summary ${ }^{b}$

\begin{tabular}{|l|l|l|l|l|}
\hline Model & $R$ & $R$ Square & $\begin{array}{l}\text { Adjusted } R \\
\text { Square }\end{array}$ & $\begin{array}{l}\text { Std. Error of } \\
\text { the Estimate }\end{array}$ \\
\hline 1 & $.697^{a}$ & .486 & .462 & 2.471 \\
\hline
\end{tabular}

a. Predictors: (Constant), KM, KP

b. Dependent Variable: KIN

Dari hasil perhitungan uji $\mathrm{R}^{2}$ yang terlihat dalam table 4.45 di atas dapat diketahui bahwa koefisien determinasi $\left(\mathrm{R}^{2}\right)$ yang diperoleh sebesar 0,697. Hal ini berarti 69,7\% variabel kinerja dapat dijelaskan oleh model dari kepemimpinan dan komunikasi, sedangkan 30,3\% dijelaskan oleh faktor lain yang tidak terdapat dalam penelitian ini.

\section{Kesimpulan}

1. Pengaruh kepemimpinan terhadap kinerja

Berdasarkan hasil dalam penelitian ini menunjukkan bahwa variabel Kepemimpinan yang diukur berdasarkan data berpengaruh secara signifikan terhadap Kinerja yang ditunjukkan dengan nilai B sebesar 0,382 dengan signifikan 0,012<0,05. Hasil tersebut dapat diketahui bahwa Kepemimpinan dapat berpengaruh signifikan terhadap Kinerja. Hasil tersebut berhasil mendukung $\mathrm{H} 1$ yang telah diajukan sebelumnya atau dapat dikatakan bahwa hipotesis diterima, ini berarti semakin tinggi nilai kepemimpinan maka semakin meningkat kinerja pegawai Kecamatan Jombang di Kota Cilegon. Hasil penelitian ini berkesesuian dengan hasil pada konteks pengaruh kepemimpinan, motivasi, lingkungan kerja dan disiplin kerja terhadap kinerja karyawan pada PT. Indonesia Power Semarang (Nicko Permana Putra,2013). Disimpulkan bahwa adanya pengaruh signifikan terhadap kinerja karyawan

2. Pengaruh komunikasi terhadap kinerja

Berdasarkan hasil penelitian ini menunjukkan bahwa variabel komunikasi berdasarkan data memperoleh nilai B 0,609 dengan signifikan sebesar 0,010<0,05. Dari hasil tersebut dapat diketahui bahwa komunikasi dapat berpengaruh signifikan terhadap kinerja. Hasil tersebut berhasil mendukung $\mathrm{H} 2$ yang telah diajukan sebelumnya atau dapat dikatakan bahwa hipotesis diterima, ini berarti semakin baik komunikasi maka semakin meningkat kinerja pegawai. Hasil ini mengindikasikan bahwa komunikasi yang terjadi berpengaruh signifikan terhadap 
kinerja pada pegawai Kecamatan Jombang di Kota Cilegon. Hasil penelitian ini berkesesuian dengan hasil pada konteks pengaruh kepemimpinan, motivasi, lingkungan kerja dan komunikasi terhadap karyawan PT. Pinnacle Apparels Semarang (Dian Venti Riandanigsih, 2014) disimpulkan terdapat pengaruh signifikan terhadap kinerja karyawan.

3. Pengaruh kepemimpinan dan komunikasi terhadap kinerja

Berdasarkan hasil signifikan uji simultan uji $\mathrm{F}$ terlihat bahwa secara bersama-sama atau simultan variabel Kepemimpinan dan Komunikasi berpengaruh positif dan signifikan. terhadap variabel Kinerja, dimana $F$ hitung sebesar19,859 $>F_{\text {tabel }}$ 3,20 dengan tingkat signifikan sebesar 0,000 $<0,05$. Berarti koefisien signifikan secara statistik Kepemimpinan dan Komunikasi secara bersama-sama berpengaruh positif terhadap Kinerja Pegawai di Kecamatan Jombang Kota Cilegon. Hasil penelitian ini berkesesuian dengan hasil pada konteks pengaruh kepemimpinan, motivasi, lingkungan kerja dan komunikasi terhadap karyawan PT.Pinnacle Apparels Semarang (Dian Venti Riandanigsih, 2014) disimpulkan terdapat pengaruh signifikan terhadap kinerja karyawan

\section{Daftar Pustaka}

Hasan, M. I. (2002). Pokok-pokok Materi Metodologi Penelitian dan Aplikasinya. Bogor: Ghalia Indonesia.

Ningsih, D. V. (2014). Pengaruh Kepemimpinan, Motivasi, Lingkungan Kerja dan Komunikasi Terhadap Kinerja Karyawan PT. Pinnacle Apparels Semarang. Semarang: Universitas Dian Nuswantoro Semarang.

Sugiyono. (2005). Metode Penelitian Administrasi. Bandung: Alpabeta.

Sugiyono. (2010). Pendekatan Kuantitatif, Kualitatif, dan R\&B. Bandung: Alpabeta.

Sugiyono. (2014). Statistika untuk Penelitian. Bandung: Alfabeta. 